\title{
Solicitors' conflict of interest: the context and significance of the new rules
}

\author{
by Chris Perrin
}

The proposed changes to the Law Society Rules governing solicitors' conflicts of interest are currently being considered by the Legal Services Consultative Panel, a statutory body that advises the Secretary of State for Constitutional Affairs on rule changes and other issues. This article is based on a presentation at a Society for Advanced Legal Studies seminar on solicitors' conflicts of interest by the author, who chaired a City of London Law Society working party which provided recommendations for conflict reform.

$\mathrm{T}$ he sub-heading for the SALS seminar from which this article is drawn stated that "the circumstances in which solicitors may, or may not, act for more than one client in the same transaction are unclear". This was certainly the case until very recently, although the position on this and related issues is, I believe, at last being resolved. The manner in which confusion has turned to clarity is itself interesting and, when understood, dispels some of the misleading suggestions which are starting to circulate in the context of the proposed changes to the Law Society Rules.

I would like to refer back to early 2000 for reasons which will become apparent. At that time, the most difficult issues for solicitors were not only whether they could act for more than one client in the same transaction, but also whether they could ever act adverse to an existing client on a matter which was unrelated to the work done for that client. I am going to consider both issues, but first, the question of acting adverse to an existing client.

\section{PRINCE JEFRI CASE}

Any solicitor seeking to get to the bottom of this basic question would look to find the answer both at common law and, separately, under the Law Society Rules. It is little short of extraordinary that, at common law, the only guidance in 2000 came in the form of dicta of Lord Justice Millett in the Prince Jefri case (Prince Jefri Bolkiah ${ }$ KPMG [1999] 2 AC 222) just over a year earlier, in November 1998. Lord Millett said (at p 234):

"a fiduciary cannot act at the same time both for and against the same client, and his firm is no better position. A man cannot without the consent of both clients act for one client while his partner is acting for another in the opposite interest".

Some thought this was pretty clear; a law firm can never act adverse to the interests of an existing client without its consent.

Against this background, the solicitor in 2000 would look to the Law Society Guide to Professional Conduct. Chapter 15.01 provides:

"a solicitor or firm of solicitors should not accept instructions to act for two or more clients where there is a conflict or a significant risk of a conflict between interests of those clients".

There is nothing here to suggest that the rule is intended to apply only to instructions on the same matter, or related matters. Even if it did, the position at common law - as Lord Millett would seem to be stating it - would render any such relaxation in the Law Society approach ineffective. Professional rules can never be less strict than those at common law.

It follows that in early 2000, there was a widespread view that an English solicitor could never act adverse to an existing client without its consent. This was not an absurd conclusion; it was, and is now, the effect of US conflict Rules. However, it was a position which was increasingly open to question for two particular reasons:

1. Commercial clients were increasingly moving away from having one firm of solicitors. Instead, they were picking one firm for one type of work, another firm for another. While it might be understandable that a firm would not act against a client which would naturally refer to it all its legal work, the perception is different where that firm only obtains a small proportion of that client's instructions. 
2. The second reason reflected the overseas ambitions of English lawyers. Over the last 40 years, English firms have increasingly operated in foreign jurisdictions and, with the advent of cross border deals, they have come to practise alongside lawyers admitted in foreign jurisdictions, and in particular in European countries. In continental Europe, it is universally the practice that a firm can act adverse to an existing client on matters unrelated to the work done for that client.

\section{WORKING PARTY ON CONFLICT REFORM}

Against this background, the Law Society embarked on a review of its rules. This was not just the conflict rules, but its entire rulebook. As part of this process, the Law Society asked the City of London Law Society to set up a working party to come up with recommendations for conflict reform which would be workable in the context of City work. In February 2000, I was asked to chair that working party.

The working party was unanimous in believing that English lawyers should be able to act adverse to the interests of a client on matters unrelated to work done for that client. It reviewed the position at common law and felt that the dicta of Lord Millett was not 100 per cent clear and, in being only dicta, should not be taken as determinative. As the eventual report said: "we are not aware of any other similar finding or dicta at law... if this is the law we would urge strongly that it be changed... if it is not changed, one of the central recommendations of this report would be impossible, and solicitors in England and Wales would remain disadvantaged within the European Union" (CCLS Report, July 2000, para 4.2).

The working party was reinforced in this recommendation by the terms of the CCBE code, which governs cross border conduct between lawyers in the European Union. That code provides:

"a lawyer may not advise, represent or act on behalf of two or more clients in the same matter if there is a conflict, or a important risk of a conflict, between the interests of those clients" (CCBE Code, October 1998, clause 3.2.1,

(emphasis added)).

Restricting the limitation to the same matter therefore reflected the general approach in Continental Europe. On cross border activities, English lawyers were required to comply with the CCBE rule as a matter of law under Practice Rule 16. More significantly, the code also provides that this provision (along with others) should be "taken into account in all revisions of national rules of deontology or professional practice with a view to their progressive harmonisation" (cl 1.3.2).

The report of my Working Party was published in July 2000. We proposed a conflict rule which defined conflict as the situation where: "a solicitor owes separate duties to act at the best interests of two or more different clients in relation to the same or related matters, and those duties conflict, or there is a significant risk that those duties will conflict".

We recognised that there was a real danger that we would be told that this proposal would not be accepted because it was less strict than the common law as set out by Lord Millett. Our concerns were highlighted by the publication - within days of the appearance of our report - of the first edition of Hollander and Salzedo on Conflicts of Interest and Chinese Walls.

In that book, the authors asked themselves whether the dicta of Lord Millett should be interpreted to apply only to conflicting instructions on the same matter. They answered by saying that, since the foundation of the rule lies in the duty of undivided loyalty which a solicitor has to a client, the correct position at common law is not simply that a solicitor cannot act adverse to a client where he is acting on the same matter for that client, but that he cannot act adverse to an existing client on any matter. They concluded that the way Lord Millett expressed himself in the Prince Jefri case was "wholly inconsistent" with the rule "being limited to 'same matter' conflicts" (Hollander \& Salzedo; Conflicts of Interest and Chinese Walls, 1st ed, para 3-22, p 27).

It was not a great start for our proposals.

The recommendations of the working party were subsequently put out for consultation by the Law Society, on two occasions. That was all that happened for some three years. The aim of the Law Society was to introduce an entire new rulebook in one go, including new conflict rules. The change to the conflict rules was therefore slowed down to accommodate the other changes. The delay on conflict reform inevitably led to criticism of the Law Society which, as a result, eventually decided in late 2003 to separate and "fast track" the conflict reform after all. The working party's proposals were to be dusted off and, subject to fine tuning, approved by the Law Society's Standards Board before being recommended to the full Council.

The Standards Board itself set up a committee to carry out the fine tuning, and I was asked to join this in January 2004. That led to a number of developments to the original proposals of the working party, before approval by the Standards Board in May 2004. One recommendation of the wording of the working party which remained essentially untouched was the definition of conflict and the limitation of its application to the "same or related matters".

Surprisingly, the disparity between the apparent position at common law (endorsed by the Hollander book) and what was being proposed was not materially challenged. The new rules were to be formal rules and therefore unlike the existing Guide to Professional Conduct - have the force of subordinate legislation. Adoption of the new rules 
therefore carried with it the prospect of legislation influencing the interpretation of Lord Millett's dicta and therefore the position at common law.

\section{MARKS \& SPENCER V FRESHFIELDS}

The conflict proposals were set to be approved by the Law Society Council on July 14, 2004. On June 2, however, Marks \& Spencer applied for an injunction to restrain Freshfields from acting for Phillip Green in a hostile bid. The application was unusual in raising not just the issue of confidential information, but also of conflict. Of direct relevance on that issue of conflict was whether the fact that Freshfields acted for Marks \& Spencer on certain matters prevented them from acting on the hostile bid.

Mr Justice Collins was, of course, referred to the dicta of Lord Millett, and he was also referred to the Hollander book. He agreed that the common law rule preventing a solicitor from acting against an existing client did more than merely stop a solicitor acting against a client on the very matter where he was acting for the client. But, critically, Mr Justice Collins said there had to be "some reasonable relationship between the two matters" for the conflict to exist (Marks \& Spencer v Freshfields, June 2, 2004. Approved draft note of judgment).

This was a vital qualification to the potential breadth of the dicta of Lord Millett and to the interpretation endorsed by Hollander \& Salzedo. Mr Justice Collins's determination that there must be "some reasonable relationship" between the two matters was satisfyingly close to the proposed definition in the new conflict rule which limited "conflict" to separate duties "in relation to the same or related matters. ${ }^{\prime \prime}$

On June 3 2004, Freshfields sought leave to appeal Mr Justice Collins's judgment. The Court of Appeal refused leave on the grounds that it had no realistic chance of success. In making that decision, Lord Justice Pill felt that there had to be "a degree of relationship" between the two transactions for a conflict to arise. The court therefore reiterated the finding of $\mathrm{Mr}$ Justice Collins, and the approach in the proposed new Law Society definition.

The conclusion of the Marks \& Spencer $v$ Freshfields case finally removed the threat that the single most important clarification which it had been hoped would be achieved through the proposed new Law Society Rules would founder because it was inconsistent with the common law. On July 15 2004, the Law Society Council approved the new rules. The DCA permitting, they will come into force in mid 2005.
I have dwelled on this element of conflict reform in some detail. I make no apology for that, because I do feel that it lay at the heart of the future approach to conflicts in this country and would, in effect, determine whether we lined up with the approach prevalent through continental Europe, or with the US approach. In my view, there is a good deal in the US approach which this country would do well to avoid.

With the last minute benefit of the judgments in Marks \& Spencer $v$ Freshfields, it is easy to forget the struggle to achieve this important clarification in the law, which was sparked by the working party report. The dicta of Lord Millett was a significant impediment, made more difficult by the endorsement of a restrictive interpretation in the first edition of Hollander and Salzedo.

In late 2004, the second edition of Hollander and Salzedo appeared, and it does of course report on the Marks \& Spencer $v$ Freshfields case. It was interesting to see how the authors had come to see things differently. To quote from their new book:

"it was always hard to imagine that Lord Millett meant what he said literally, and it was always unlikely that he intended to say that the double employment matter prevented a professional acting on opposite sides in unrelated matters. There had surely to be as a matter of common sense some limitation on the principle... it was always probable that Lord Millett had in mind the case where there was some relationship between the two matters such as to bring the principle of conflict into play (Hollander \& Salzedo, 2nd ed, para 2-58, p 31).”

This represents a significant change of opinion. Moreover, it could be said that the authors now go overboard in characterising as unrealistic the approach they adopted in 2000; it is worth bearing in mind that that same approach underpins conflict law throughout the United States.

So, it is now fair to say that the circumstances in which solicitors may act adverse to the interests of an existing client are becoming a lot clearer.

I would like to move on to consider the circumstances in which a solicitor can act for more than one client in the same transaction. In particular, I will look at the relevant provisions in the new Law Society Rules in greater detail, and give some views on what these mean for solicitors and their clients in practical terms.

\section{MISCONCEPTIONS ABOUT THE NEW RULES}

Before I do that, there are just two misconceptions about the new rules which I would like to correct. 
Unfortunately, both of these misconceptions are recorded in the second edition of Hollander and Salzedo. Do not get me wrong; this is for the most part a very good and valuable book. The reason why I keep on making reference to it is largely because it is the only book to comment on the new rules.

The first misconception is that the review of the Law Society Rules was "intended to give flexibility to large firms" (Hollander and Salzedo, 2nd ed, para 11-235, p 204: I understand that the misconception sprang from a speech given at the Law Society Council meeting which approved the new rules and, if that is the case, that speech similarly misrepresented the background to the review).

As everyone recognised, the former Law Society Rules were in desperate need of updating. But the real trigger was the fact that the Law Society decided that the advent of the new millennium was a good time to embark on a review of its entire rulebook. Prior to this, City firms were not complaining about the status quo on conflicts; the Law Society Rules had very little application because they were so unclear, but there was a reasonably good unwritten acceptance within the City as to what was, or was not a conflict. It was not an environment where there were regular complaints by clients or anyone else.

When the Law Society decided on the review, it asked the City of London Law Society to make some proposals because the Law Society was keen to ensure that any proposed amendments would make sense in the context of City work. Contrary to the suggestion recorded by Hollander and Salzedo, my working party sought to propose a balanced and responsible new code. We did not seek to put forward a regime which would enable City firms to do as they wished. I think everyone recognised that any new set of rules would, in practice, involve a tightening in comparison with the de facto regime. Having got our proposals, the Law Society itself (primarily through its Standards Board) had input on the wording, and made some of the provisions more restrictive. I believe the result is a regime which is workable, and a huge improvement on what we have had, but it certainly does not purport simply to liberate City firms, and nor was it ever intended to do so.

The second misconception is that the Law Society would have done better simply to have left the whole issue of conflicts and confidentiality to the common law. This suggestion misses the point in two respects. First, the common law on conflict (as opposed to protection of confidential information) was too unclear - right up until June 2004 - for any regulatory body responsibly to rely upon it as sole indication of its professional rules. Secondly the Law Society did, in some respects, deliberately want rules which were more strict than the common law. Let me give two examples:

1. The Law Society wanted to make it clear that a solicitor's duty to disclose to a client any information the solicitor has which is relevant to a retainer relates to information from any source, and not just information obtained from acting on that retainer.

2. In a Prince Jefri situation, the Law Society believed that the client / former client to which the firm owed a duty of confidentiality should always consent. The law firm should not be able to erect walls, even to the Prince Jefri standard, without the client / former client knowing, and therefore having the chance to challenge what the firm is doing before - perhaps - it is too late to preserve confidentiality.

Examples such as these demonstrate, of course, that the purpose of the new rules was not simply "intended to give flexibility to large firms" (Hollander and Salzedo, 2nd ed, para 11-235, p 204).

\section{ACTING FOR MORE THAN ONE CLIENT IN SAME OR RELATED TRANSACTION}

I now come to what the new rules say in detail about a solicitor acting for more than one client in the same transaction, or related transaction.

First, a few words on the meaning of "same or related matters". This phrase is not defined, although some guidance is provided. In particular, it is made clear that two matters involving the same asset or liability would always be treated as "related" (clause 2(d)). In addition, the explanatory notes which provide guidance to the rule state that there must be some "reasonable degree of relationship for a conflict to arise". Personally, I do not believe that it would have been helpful to seek to define these terms with any more precision. It is also worth bearing in mind that many continental European countries have similar wording and do not encounter any significant difficulty in applying it.

There are then two exceptions to the basic rule that a firm cannot act for more than one client on the same or related matters. Both of these are very applicable to City practice, and answer issues left unclear in previous Law Society Rules. The first exception (which is also applicable to High Street practice) provides that, subject to informed written consent from all clients, the solicitor / firm may:

$$
\begin{aligned}
& \text { "act for two or more clients in relation to a matter in } \\
& \text { situations of conflict or possible conflict if the different clients } \\
& \text { have a substantially common interest in relation to that } \\
& \text { matter or a particular aspect of it". }
\end{aligned}
$$

The formal guidance explains that for there to be "common interest" there must be a clear common purpose and a strong consensus on how it is to be achieved. In deciding whether it is appropriate to act, the solicitor must consider whether the clients will be represented evenhandedly with equal weight being given to the instructions from each. It is also for the solicitor to keep the differences between the respective clients under review and to decide if the point has been reached when it would be untenable 
to continue to represent all of them in a fair and open manner or without any of them being prejudiced.

In terms of work typically done by City firms, this exception is likely to be applied in situations like the following:

(i) Where acting for a borrower and parent company guarantor on a financing.

(ii) Where acting for arrangers on a note programme, and also for the trustees.

(iii) Where acting for lenders on a syndicated loan and advising on an inter-creditor agreement between them.

(iv) Where acting for joint venture partners in seeking to achieve a specific contract.

Where a firm is acting for two clients who have a common interest and material differences subsequently arise, it is of course open to the firm to cease to act for one or both clients on the particular issue which gives rise to the difference. With that issue carved out - and if necessary being dealt with by another firm - the rest of the transaction can continue to be handled within the terms of the exception.

The second exception, which is again subject to written client consent, permits a firm to act for two or more clients in relation to a matter in situations of conflict or possible conflict if:

"the clients are competing for the same asset which, if attained by one client, will make that asset unattainable to the other client(s), and there is no other conflict, or significant risk of conflict, between the interests of any of the clients in relation to that matter".

This exception is primarily aimed at two situations. The first is the public auction of a business. The exception permits a firm to act for competing bidders in the early stages of the auction process, i.e. through to the point where a preferred bidder is chosen, with detailed contract terms then being negotiated by that preferred bidder. This exception therefore respects what has become City practice.

The exception is particularly applicable and relevant to the flourishing private equity market which is based in the City. In that relatively rarefied environment, a private equity house would expect to be able to retain the advisors of its choice, whether financial advisers, accountants, lawyers or other consultants. To be able to select their preferred advisers, they are generally happy to accept that the same banks/firms can act for competing interests behind suitable information barriers. It is worth noting that it is not unusual for law firms to act for competing interests in a similar way in a number of continental
European jurisdictions (although the Swedish bar last year refused to sanction this practice).

The other type of work which the second exception seeks to cover relates to insolvencies and refinancings. The intention is to ensure that a firm can act for more than one client in such situations, even where they may be competing for limited assets. In theory, this could permit a firm to embark on litigation adverse to another client, but it may well be that a firm would agree with the relevant clients that its roles would fall short of such action. Although neither the exception nor the associated guidance makes the position entirely clear, I would submit that the exception also permits a firm to advise competing clients prospectively on how assets would be split in the event of an insolvency / restructuring. This would therefore justify a firm acting for creditors on the preparation of an inter-creditor agreement, in those situations where the work did not already fall within the "common interest" exception.

There are various further provisions which apply when a firm seeks to rely on either of the exceptions. In particular, there is a "catch-all" provision whereby the firm must only act where it is objectively reasonable in all the circumstances to do so. There are also provisions dealing with the information which must be given to all clients so that they can be properly informed before giving their necessary consent.

\section{CONCLUSION}

Five years ago, a law firm did not know when or whether it could ever act adverse to an existing client, or if it could act for more than one client on a transaction. Once the new Law Society Rules are properly in place, I believe the situation will be acceptably clear under both the common law and the professional rules. The Law Society Rules will have the status of subordinate legislation and the courts will therefore be able to enforce them in a way which they have never sought to do so in the past. Quite how this will work out, we will have to wait to see. However, on these issues we now have respectable regimes and the change from where we were - to where we are now arriving - is worth remembering. As we have seen, memories are very short and it is easy to forget the background, the context against which the changes were made and, therefore, the significance of them.

- The SALS seminar on solicitors' conflicts of interest from which this article is taken was held on November 25, 2004.

\section{Chris Perrin}

Executive Partner and General Counsel, Clifford Chance LLP; chairman,

City of London Law Society Working Party on Review of Conflict Rules 


\section{SOLICITORS' PRACTICE (CONFLICT) AMENDMENT RULE [2004]}

Rule dated [the date of the Lord Chancellor's approval] made by the Council of the Law Society, under section 31 of the Solicitors Act 1974 and section 9 of the Administration of Justice Act 1985 with the concurrence of the Master of the Rolls under the latter section and the approval of the Lord Chancellor under schedule 4 to the Courts and Legal Services Act 1990.

Amend rule 16 of the Solicitors' Practice Rules 1990 by making a new rule $16 \mathrm{D}$ as set out below.

\section{(1) (Introduction)}

(a) This rule sets out provisions for dealing with conflicts of interest other than those conflicts in relation to conveyancing, property selling or mortgage related services which are dealt with in rule 6.

(b) This rule applies to a regulated individual and a regulated practice.

(c) Conflicts between the duty of confidence and duty of disclosure owed by an individual or a practice to two or more clients are dealt with in rule $16 \mathrm{E}$

\section{(2) (Duty not to act)}

(a) You must not act if there is a conflict of interests (except in the limited circumstances dealt with in paragraph (3)).

(b) There is a conflict of interests if:

(i) you owe, or your practice owes, separate duties to act in the best interests of two or more clients in relation to the same or related matters, and those duties conflict, or there is a significant risk that those duties may conflict; or

(ii) your duty to act in the best interests of any client in relation to a matter conflicts, or there is a significant risk that it may conflict, with your own interests in relation to that or a related matter.

(c) In criminal matters there will be a presumption there is a conflict of interests in representing more than one client in the same proceedings unless the solicitor can show that special circumstances apply to rebut this presumption and that these circumstances have been noted on the file.

(d) For the purpose of paragraph (2)(b) above, a related matter will always include any other matter which involves the same asset or liability.

\section{(3) (Exceptions to duty not to act)}

(a) You or your practice may act for two or more clients in relation to a matter in situations of conflict or possible conflict if:

(i) the different clients have a substantially common interest in relation to that matter or a particular aspect of it; and

(ii) all the clients have given in writing their informed consent to you or your practice acting.

(b) Your practice may act for two or more clients in relation to a matter in situations of conflict or possible conflict if:

(i) the clients are competing for the same asset which, if attained by one client, will make that asset unattainable to the other client(s);

(ii) there is no other conflict, or significant risk of conflict, between the interests of any of the clients in relation to that matter;

(iii) the clients have confirmed in writing that they want your practice to act in the knowledge that your practice acts or may act for one or more other clients who are competing for the same asset; and

(iv) unless the clients specifically agree, no individual solicitor acts for, or is responsible for the supervision of, more than one of those clients.

(c) When acting in accordance with paragraphs (3)(a) or (b) above it must be reasonable in all the circumstances for you or your practice to act for all those clients.

(d) If you are relying on the exceptions in paragraphs (3)(a) or (b) above, you must:

(i) draw all the relevant issues to the attention of the clients before agreeing to act or, where already acting, when the conflict arises or as soon as is reasonably practicable, and in such a way that the clients concerned can understand the issues and the risks involved; and

(ii) have a reasonable belief that the clients understand the relevant issues; and

(iii) be reasonably satisfied that those clients are of full capacity.

\section{(4) (Conflict when already acting)}

If you act, or your practice acts for more than one client in a matter and, during the course of the conduct of that matter, a conflict arises between the interests of two or more of those clients, you, or your practice, may only 
continue to act for one of the clients (or a group of clients between whom there is no conflict) provided that the duty of confidentiality to the other client(s) is not put at risk.

\section{(5) (Accepting gifts from clients)}

Where a client proposes to make a lifetime gift or a gift on death to, or for the benefit of,
(a) you;
(b) any proprietor or employee of the practice; or
(c) a family member of any of the above

and the gift is of a significant amount, in itself or having regard to the size of the client's estate and the reasonable expectations of the prospective beneficiaries (unless the client is a member of the beneficiary's family), you must advise the client to take independent advice about the gift. If the client refuses, you must stop acting for the client in relation to the gift.

\section{(6) (Public office or appointment leading to conflict)}

You must decline to act where you, or another proprietor or employee in your practice, or a member of your family holds some public office or appointment as a result of which:

(a) a conflict of interests, or a significant risk of a conflict, arises, or

(b) the public might reasonably conclude that you, or your firm, had been able to make use of the office or appointment for the advantage of the client, or

(c) your ability to advise the client properly and impartially is inhibited.

\section{(7) (Waivers)}

Notwithstanding Rule 17 of these rules, the Council of the Law Society shall not have power to waive any of the provisions of this rule.

\section{SOLICITORS' PRACTICE (CONFIDENTIALITY AND DISCLOSURE) AMENDMENT RULE [2004]}

Rule dated [the date of the Lord Chancellor's approval] made by the Council of the Law Society, under section 31 of the Solicitors Act 1974 and section 9 of the Administration of Justice Act 1985 with the concurrence of the Master of the Rolls under the latter section and the approval of the Lord Chancellor under schedule 4 to the Courts and Legal Services Act 1990.

Amend rule 16 of the Solicitors' Practice Rules 1990 by making a new rule $16 \mathrm{E}$ as set out below.

\section{(1) (Introduction)}

(a) This rule sets out provisions for dealing with the protection of clients' or former clients' confidential information and the duty of disclosure owed to clients.

(b) This rule applies to a regulated individual and a regulated practice.

\section{(2) (Duty of confidentiality)}

You and your practice must keep the affairs of clients and former clients confidential except where disclosure is required or permitted by law or by your client or former client.

\section{(3) (Duty of disclosure)}

You must disclose to a client all information of which you are aware which is material to that client's matter regardless of the source of the information unless:

(i) there is a duty of confidentiality as referred to in paragraph (2) above, which always over-rides the duty to disclose; or

(ii) the following circumstances exist, as a consequence of which the duty does not apply:

(a) such disclosure is prohibited by law;

(b) it is agreed expressly that no duty to disclose arises or a different standard of disclosure applies; or

(c) you reasonably believe that serious physical or mental injury will be caused to any person if the information is disclosed to a client.

\section{(4) (Duty not to put confidentiality at risk by acting)}

If you hold, or if your practice holds, confidential information in relation to a client or former client, you must not risk breaching confidentiality by acting, or continuing to act, for another client on a matter where

(i) that information might reasonably be expected to be material; and

(ii) that client has an interest adverse to the firstmentioned client or former client

except where proper arrangements can be made to protect that information in accordance with paragraph 5 below.

\section{(5) (Exception to duty not to put confidentiality at} risk by acting - where clients consent)

(a) You may act, or continue to act, in the circumstances otherwise prohibited by paragraph (4) above with the informed consent of both clients but only if; 
(i) the client for whom you act or are proposing to act knows that your practice, or a member of your practice, holds, or might hold, material information (in circumstances described in paragraph (4) above) in relation to their matter which you cannot disclose; and

(ii) you have a reasonable belief that both clients understand the relevant issues after these have been brought to their attention; and

(iii) both clients have agreed to the conditions under which you will be acting or continuing to act; and

(iv) it is reasonable in all the circumstances to do so.

(b) "Both clients" in the context of paragraph (5) means:

(i) an existing or former client for whom your practice, or a member of your practice, holds confidential information; and

(ii) an existing or new client for whom you act or are proposing to act and to whom information held on behalf of the other client is material (in circumstances described in paragraph (4) above).

(c) If you, or you and your practice, have been acting for two or more clients in reliance on rule $16 \mathrm{D}$ (3) (the conflict rule) and can no longer fulfil its requirements you may continue to act for one client with the consent of the other client provided you comply with paragraph (5).
(6) (Exception to duty not to put confidentiality at risk by acting - where no clients consent)

You may continue to act for a client on an existing matter, or on a matter related to an existing matter, in the circumstances otherwise prohibited by paragraph (4) above without the consent of the client or former client for whom your practice, or a member of your practice, holds, or might hold, confidential information which is material to your client (in circumstances described in paragraph (4) above) but only if:

(a) it is not possible to obtain informed consent under paragraph (5) above from the client or former client for whom your practice, or a member of your practice, holds, or might hold, material confidential information; and

(b) your client has agreed to your acting in the knowledge that your practice, or a member of your practice, holds, or might hold, information material to their matter which you cannot disclose; and

(c) safeguards which comply with the standards required by law at the time they are implemented are put in place; and

(d) it is reasonable in all the circumstances to do so.

\section{(7) (Waivers)}

Notwithstanding Rule 17 of these rules, the Council of the Law Society shall not have power to waive any of the provisions of this rule. 